\title{
A ritka betegségek ellátásának aktuális kérdései
}

\author{
Pogány Gábor dr.
}

Ritka és Veleszületett Rendellenességgel Élők Országos Szövetsége, Budapest

\begin{abstract}
A közlemény célja a ritka betegségek jelenlegi helyzetének és ezen belül a magyarországi állapotának a leírása. Bemutatjuk a közelmúlt nemzetközi és hazai fejleményeit, amelyek ismerete elősegítheti a mindennapi orvosi gyakorlatban a ritka betegek ellátását. A ritka betegséggel élők az egészségügyi ellátórendszer számára sokszor „láthatatlanok”, mert csak néhány ilyen betegségnek van betegségek nemzetközi osztályozási (BNO-) kódja. A körülbelül 800000 ritka beteg a gyakori megbetegedésben szenvedőkhöz képest is óriási hátrányban van. Fontos nemzeti és nemzetközi lépések történtek az utóbbi időben e hátrányok csökkentésére. A magyar Ritka Betegségek Szakértőii Központok hivatalosan kinevezésre kerültek, és így számos egészségügyi szolgáltató csatlakozni tudott a megalakuló európai referenciahálózatokhoz. A Ritka és Veleszületett Rendellenességgel Élők Országos Szövetsége létrehozta a ritkabetegségspecifikus Mentőöv Információs Központ és Segélyvonalat. Ezek a lépések elősegítik a Ritka Betegségek Nemzeti Terv végrehajtását, annak ellenére, hogy annak a formális elfogadási folyamata ideiglenesen megakadt az egészségügy háttérintézményeinek újraszervezése miatt. E fejlemények hozzájárulhatnak a betegutak jobb kialakításához, és így lerövidíthetik az érintett családok bolyongását az egészségügyi, oktatási és szociális ellátások labirintusában. A ritka betegségekben szenvedők ellátásával kapcsolatos nemzeti stratégia megvalósítása szükséges ahhoz, hogy javítsunk a ritka betegeket ellátó egészségügyi szolgáltatások rendszerének jelenlegi szervezettségén és hatásosságán, hogy felkészítsük az egészségügyi, oktatási, szociális szakembereket és magukat a betegeket is a rendszer minél jobb kihasználására. A tervszerú ellátás célja, hogy minden ritka beteg a lehető legrövidebb idő alatt kapjon diagnózist annak érdekében, hogy időben hozzáférhessen a szükséges ellátáshoz és támogatáshoz, végeredményben csökkentve a beteg és családja megpróbáltatásait és a társadalom terheit.
\end{abstract}

Orv Hetil. 2017; 158(47): 1851-1856.

Kulcsszavak: nemzeti terv, szakértői központ, európai referenciahálózat, Mentőöv Információs Központ és Segélyvonal, ritka betegek szövetsége

\section{The actual questions of the care of rare diseases}

The aim was to present the actual situation of rare diseases, especially to characterize the circumstances in Hungary. The most important developments were summarized which could help the care of rare disease patients in the everyday practice.

There are around 800000 patients with rare diseases in Hungary. The lack of information leads to „invisibility” for the health and social care system (most of them without ICD code). Therefore, these patients still have a huge disadvantage even when compared to the patients of common diseases. Important national and international measures took place in the last years to decrease these disadvantages. The Hungarian Centres of Expertise were officially approved, thus several health care providers were able to get membership in the forming European Reference Networks. The rare disease specific "Lifebelt" Information Centre and Help Line was established by HUFERDIS. These steps assist the implementation of the National Rare Disease Plan, although its formal approval process has temporarily stopped because of the reorganization of the health care system.

The summarized developments can contribute to define better patient directions, and thus decrease the family knocks about the maze of health, social and educational systems. The realization of Rare Disease National Strategy is needed to improve the current fragmentation of services and enable patients and health, social and educational professionals to provide and use best practice care. This will ensure that all patients with rare disease cannot only be diagnosed quickly, but also have timely access to the care and support that they need, resulting in a decreasing burden of families and society.

Keywords: rare diseases, National Strategy, Centre of Expertise, European Reference Network, "Lifebelt" Information Centre, Federation of Rare Diseases Patients - HUFERDIS

Pogány G. [The actual questions of the care of rare diseases]. Orv Hetil. 2017; 158(47): 1851-1856.

(Beérkezett: 2017. augusztus 16.; elfogadva: 2017. szeptember 21.) 


\section{Rövidítések}

BNO = betegségek nemzetközi osztályozása; EESzT = Elektronikus Egészségügyi Szolgáltatási Tér; $\mathrm{ePAG}=($ European Patient Advocacy Group) Európai Betegképviseleti Csoport; $\mathrm{ERN}=($ European reference network $)$ európai referenciahálózat; EU = Európai Unió; EURORDIS = (European Organisation of Rare Diseases) Ritka Betegségek Európai Szervezete; $\mathrm{ICD}=($ International Classification of Diseases $) ; \mathrm{RB}=($ rare disease) ritka betegség; RIROSZ = (HUFERDIS: Hungarian Federation of People with Rare and Congenital Diseases) Ritka és Veleszületett Rendellenességgel Élők Országos Szövetsége

„Nem mindig lebet megtenni, amit kell, de mindig meg kell tenni, amit lehet." (Bethlen Gábor)

A jelen tanulmány célja összefoglalni azokat a fontos, közelmúltbeli hazai és európai fejleményeket, amelyek ismerete megkönnyítheti a mindennapi orvosi gyakorlatot, hiszen egy ritka betegséggel szembekerülő szakember sokszor érezheti úgy, hogy a lehetetlenre vállalkozik, amikor segíteni próbál a betegen. A minden oldalú erőforráshiány szélsőséges esetét példázó ritka betegségeknél az általános információhiány miatt nehéz a betegutak megtalálása, kialakítása. A betegek és szakembereik is úgy érezhetik magukat, mint a régi sarkkutatók, akik magukra utaltan, hosszú nappalokon és éjszakákon át bolyongtak a nagy fehérségben, szinte segítség és támpont nélkül. Szerencsére az utóbbi évtizedekben, a szívós hazai és nemzetközi együttmúködés eredményeként, jelentős haladás történt ezen az előzőekben elhanyagolt területen is.

\section{A Ritka Betegségek Szakértői Központok szerepe a mindennapi orvosi gyakorlatban, úgy is mint a Ritka Betegségek Nemzeti Terv pillérei}

Ritka betegségnek (RB) Európában az olyan, életet fenyegető vagy krónikus rokkantságot okozó betegséget nevezzük, amelynek prevalenciája alacsony $(<1 / 2000)$, és speciális, összetett feladatot jelent a velük való foglalkozás [1]. Bár egy betegség csak néhány beteget sújt, mivel több mint 6000-8000-féle ritka betegség ismert, ezért e betegségek akár 800000 embert is érinthetnek hazánkban (Európában körülbelül 27-36 milliót) [2, 3]. Összességükben a ritka betegségek tehát nem ritkák, ezért kezeli az Európai Unió (EU) is népegészségügyi prioritásként a jogaik és esélyegyenlőségük biztosítását $[3,4]$. Európa-szerte komoly szakmai erőfeszítések történnek annak érdekében, hogy e betegcsoportba tartozók ellátása, a betegségek korai felismerése, megfelelő kezelése megtörténjen.

A súlyos, ritka betegséggel élők óriási hátrányban vannak, még a gyakori betegségben szenvedő betegtársaikhoz képest is. Az egyenként keveseket érintő betegségek ismereteinek hiánya miatt kevés a hozzáértő szakember, így sokáig nincs megfelelő diagnózis, és ezért adekvát kezelést sem tudnak kapni az érintettek $[5,6]$. A sok felesleges kezelés hatalmas terhet jelent az egészségügy számára is [6]. Az érintettek nem találnak sorstársakra, a szakmai oldalról kevés a kutatás, a gyógyszer, az ellátási tapasztalat [7]. A legtöbb esetben a ritka betegség a helyes kezelés megtalálása esetén sem gyógyítható, de a betegek képességei fejleszthetőek, és az állapotuk a legtöbb esetben lényegesen javítható.

Mindezen gondok megoldására az Európai Tanács ajánlásainak is megfelelően [8] született meg hazánkban a 2020-ig szóló Ritka Betegségek Nemzeti Terve szakpolitikai stratégia [9]. E szakmai program kidolgozása 2009 és 2014 között, minden érdekcsoport bevonásával, széles körű egyeztetéssel, nemzetközi együttmúködésben valósult meg, ami végeredményben az érintettek teljes egyetértését tükrözte. A program elkészítése során a Ritka és Veleszületett Rendellenességgel Élők Országos Szövetsége (RIROSZ) [10] eddig két nemzeti és két nemzetközi konferenciát rendezett (idén október 20-án volt az ötödik, mely már a megvalósítással foglalkozott). A projekt magyar honlapján [11] minden szükséges háttéranyag, a konferenciák összes anyaga, valamint az elkészített hivatalos dokumentumok is megtalálhatók. Hasonló szerepet tölt be a RIROSZ által évente megrendezésre kerülő Ritka Betegségek Világnapja is (minden év február utolsó hétvégéjén), amely tevékenyen segíti elő a kérdésnek a nagyobb nyilvánosság számára való újból és újból hozzáférhetővé tételét [12]. A stratégia angol verzióját, az emberi erőforrások miniszterének engedélyével, 2013 őszén küldték ki az Európai Unió számára, azonban egy szükséges közigazgatási eljárás keretén belül itthon még nem került elfogadásra. A Ritka Betegségek Nemzeti Terve kitér a szakemberek megfelelő képzésére, a szükséges diagnosztikus eszközökkel, személyi és technikai háttérrel rendelkező szakértői központok létrehozására, racionalizált betegutak kialakítására, valamint a határokon átívelő egészségügyi ellátás megszervezésére is. Sajnálatos, hogy költségvetés nincs hozzárendelve a terv végrehajtásához, így a finanszírozást általánosságban az egészségügyi kiadások részeként kellene megvalósítani. Az intézményi átszervezések során kialakult új államtitkársági struktúrában a $R i t k a B e-$ tegségek Nemzeti Terv végrehajtása az Országos Tiszti Főorvosi Feladatokért Felelős Helyettes Államtitkárság Egészségfejlesztési és Szűrési Koordinációs Főosztályához került [13].

A nemzeti tervvel összhangban, többéves szervezőmunka után, 2015 nyarán hivatalosan is kinevezésre kerültek a Ritka Betegségek Szakértôi Központjai a velük együttmúködő kisebb gyógyító központokkal együtt (gyakorlatilag a négy orvosi egyetem e betegekkel foglalkozó hálózatai). Ez a tény azért volt örvendetes, mert így az ellátóhelyek „láthatóbbá” váltak, a betegutak szervezése könnyebbé vált, és nem utolsósorban lehetőségük 
nyílt, a most megalakult európai referenciahálózatokhoz (ERN) történő csatlakozásra [14].

A Ritka Betegségek Szakértői Központjai, a többi európai országhoz hasonlóan, már eddig is több helyen múködtek hazánkban, néhol csak egy-egy ritka betegségre vagy bizonyos csoportjukra szakosodva, máshol pedig a ritka betegségek széles spektrumával foglalkozva. Azonban ezek az ellátóhelyek spontán alakultak ki, az ott dolgozó szakemberek érdeklődésének megfelelően, öszszehangolás, szabályozottság és hivatalos elismertség nélkül. A betegek között sokszor „szájhagyomány” útján terjedt, hogy „hova érdemes menni”, és az egész rendszerre az esetlegesség volt jellemző. Esetleges volt, hogy egy szakember hajlandó-e „hobbiként” beleásni magát egy-egy speciális szakterületbe, és esetleges volt az is, hogy az „odatartozó” ritka betegnek sikerül-e és mikor a megfelelő ellátóhelyre jutnia. Többször csak felnőttkorban kiteljesedő kórképekról is szó van, amely egészen speciális szemléletet követel, és sokszor lehet magyarázata a késedelmes diagnosztikának [15]. A fentiek is szerepet játszanak abban, hogy a ritka betegségben szenvedók hátrányosabb helyzetben érezhetik magukat a gyakori betegségben szenvedókhöz képest is [16]. A velük való kielégítő foglalkozás egyedüli útja az erőforrás-koncentráció, vagyis az ellátás központokba szervezése. Csak ebben az esetben koncentrálható a szükséges tudás, hiszen csak ekkor tud a szakember is elegendő számú beteggel találkozni, megfelelő mértékú tapasztalatot szerezni. Egyes, igen alacsony előfordulási gyakorisággal bíró ritka betegségek esetén csak legalább kontinensmértékü öszszefogással lehet kielégítően ellátni ezeket a betegeket. Vagyis elég lehet egész Európában néhány „betegségspecifikus" szakértői központ, ahol viszont az összes hasonló beteget el tudják látni. Ehhez azonban a szakembereknek és a szakértői központoknak láthatóknak kell lenniük és tudniuk kell egymásról, hogy pontosan hol, ki, mihez ért. Ezért kell a szakértői központokat kontinensszintû́ hálózatba szervezni.

\section{A szakértői központok európai referenciahálózatai}

A 24 európai referenciahálózat létrehozása történelmi jelentőségú lépés, hiszen az EU ezzel megkezdte a nagyon különböző tagállami egészségügyi rendszerek harmonizálását, annak ellenére, hogy eddig nem finanszírozott ilyesmit, mivel az egészségügy tagállami kompetencia. A fó cél, hogy a különböző országok közti ellátásbeli különbségek végül megszúnjenek! Egy-egy hálózat célja egy ritka betegség- vagy egy hasonló szükségletekkel rendelkező betegcsoport ellátási, gondozási minőségének javítása. Ezen együttmúködés több európai ország központjainak tudás- és tapasztalati hálózata. $\mathrm{Az}$ összeurópai tudás és tapasztalat a nemzeti szinten meglevő lehetôségek kiegészítésével, támogatásával éri el a minőségbeli javulást. A különböző hálózati aktivitás alapelve, hogy elsősorban a tapasztalatot osszák meg, vagyis inkább a tudás mozogjon, ne pedig a beteg kényszerüljön utazni, amikor csak lehet. Minden európai beteg előnyére szolgál majd egy ilyen rendszer, még akkor is, ha egy adott hálózat szakértői központjai nem minden országban találhatók majd meg!

A betegségek rendkívül nagy száma miatt lehetetlen lenne mindegyik számára egy külön hálózatot létrehozni és menedzselni. Ezért a Ritka Betegségek Európai Szakértôi Bizottsága hosszú munkával kidolgozta és elfogadta, hogy milyen betegségcsoportoknak lesz ERN-je. A csoportosítás többféle elv figyelembevételével történt: diagnosztikai módszertan, klinikai szakterület (például neurológia, nefrológia), klinikai csoportok (például genetikai betegségek, metabolikus betegségek), intervenciós területek (például transzplantációk, génterápiák) tekintetbevételével. Az Európai Bizottság végül $24 \mathrm{ERN}$ létesítését határozta el ez év tavaszán, amelyekben több mint 900 egészségügyi szolgáltató vesz részt, több mint 300 kórházból, 26 tagállamból. Hazánkból a négy RB szakértői központ 13 egészségügyi szolgáltatója tudott csatlakozni, ahogy az 1. táblázat mutatja. A legtöbb hálózatba a Pécsi Tudományegyetem három klinikája tudott bekapcsolódni, míg a legtöbb klinika a Semmelweis Egyetemról csatlakozott.

Sajnos tizenkét hálózatban még nincs magyar partner, annak ellenére, hogy léteznek nemzetközi hírú tudományos csoportjaink e területek többségén. Fontos megemlíteni, hogy az ERN-ek uniós támogatásban részesülnek majd mind az ellátás koordinációjára, mind további kutatások finanszírozására. Célként fogalmazható meg, hogy további hazai szolgáltatók bekapcsolódásával ne maradjon hálózat magyar résztvevő nélkül.

Az ERN-ek létesítésének és munkájának elősegítésére az EURORDIS már 2016-ban elindította az európai betegképviseleteket (European patient advocacy groups ePAGs). A képviselőket demokratikusan választották meg, ók részt vesznek a referenciahálózatuk gyúlésein, összegyújtik a betegeik véleményét, ezeket továbbítják a hálózatoknak. Közel 100 ePAG-képviselő között csupán három magyar van még, a következő választások 2018ban esedékesek.

\section{Az Orphanet szerepe}

Az Orphanetet (www.orpha.net) 1997-ben a franciák alapították, amely az Európai Bizottság támogatásával a BNO-11 kidolgozásának fontos múhelyévé vált. A gondot az okozza, hogy a jelenleg a világ legtöbb országában alkalmazott BNO-10-ben a sokezernyi ritka betegségből csak körülbelül 250 rendelkezik BNO-kóddal, vagyis e betegségek zöme láthatatlan a statisztikáink és finanszírozási rendszereink számára, akadályozva az optimális ellátásszervezést. Így a BNO-11 tervezése során több ezer ritka betegséget is kívánatos megfelelő kóddal ellátni. A már 40 ország közremúködéséből álló Orphanet konzorcium ezért dolgozta ki az „Orphanet ritka betegség nómenklatúráját” (Orpha-kódok), amely nél- 
1. táblázat |A létrejött európai referenciahálózatok, a magyar szakértői központokból csatlakozott egészségügyi szolgáltatókkal

\begin{tabular}{|c|c|c|c|c|c|}
\hline Referenciahálózat & & Budapest & Debrecen & Pécs & Szeged \\
\hline ERN RITA & $\begin{array}{l}\text { Immunológiai és } \\
\text { autoinflammációs } \\
\text { betegségek }\end{array}$ & & $\begin{array}{l}\text { DE KK Bőr- } \\
\text { gyógyászati Klinika }\end{array}$ & & \\
\hline ERN BOND & Csontbetegségek & & & & \\
\hline ERN EURACAN & $\begin{array}{l}\text { Felnőttkori rákok (szolid } \\
\text { tumorok) }\end{array}$ & $\begin{array}{l}\text { Országos Onkológiai } \\
\text { Intézet }\end{array}$ & & & \\
\hline $\begin{array}{l}\text { ERN GUARD- } \\
\text { HEART }\end{array}$ & Szívbetegségek & & & & \\
\hline ERN ReCONNET & $\begin{array}{l}\text { Kötőszöveti, izom- és } \\
\text { csontrendszeri betegségek }\end{array}$ & & & & \\
\hline ERN ITHACA & $\begin{array}{l}\text { Veleszületett fejlődési } \\
\text { rendellenességek és ritka } \\
\text { értelmi akadályozottságok }\end{array}$ & & & $\begin{array}{l}\text { PTE Klinikai } \\
\text { Központ Orvosi } \\
\text { Genetikai Intézet }\end{array}$ & \\
\hline Endo-ERN & Endokrin betegségek & $\begin{array}{l}\text { SE II. Belgyógyászati } \\
\text { Klinika }\end{array}$ & & & \\
\hline ERN EYE & Szembetegségek & & & & \\
\hline $\begin{array}{l}\text { ERN TRANS- } \\
\text { PLANT-CHILD }\end{array}$ & Gyermektranszplantáció & & & & \\
\hline ERN EuroBloodNet & Hematológiai betegségek & & & & \\
\hline ERN CRANIO & $\begin{array}{l}\text { Archasadékok és orr-, fül-, } \\
\text { gégerendellenességek }\end{array}$ & & & $\begin{array}{l}\text { PTE Klinikai } \\
\text { Központ Orvosi } \\
\text { Genetikai Intézet } \\
\end{array}$ & \\
\hline ERN RARE-LIVER & Májbetegségek & & & & \\
\hline MetabERN & $\begin{array}{l}\text { Öröklődő metabolikus } \\
\text { rendellenességek }\end{array}$ & & $\begin{array}{l}\text { DE KK RBSZK és } \\
\text { Klinikai Genetikai } \\
\text { Tanszék }\end{array}$ & & \\
\hline VASCERN & $\begin{array}{l}\text { Ritka multiszisztémás } \\
\text { vascularis betegségek }\end{array}$ & $\begin{array}{l}\text { SE Városmajori Szív- és } \\
\text { Érgyógyászati Klinika }\end{array}$ & & & \\
\hline ERN-RND & Neurológiai betegségek & $\begin{array}{l}\text { SE Genomikai Medicina } \\
\text { és Ritka Betegségek } \\
\text { Intézete }\end{array}$ & & $\begin{array}{l}\text { PTE Klinikai } \\
\text { Központ Orvosi } \\
\text { Genetikai Intézet }\end{array}$ & \\
\hline ERN EURO-NMD & $\begin{array}{l}\text { Neuromuscularis } \\
\text { betegségek }\end{array}$ & $\begin{array}{l}\text { SE Genomikai Medicina } \\
\text { és Ritka Betegségek } \\
\text { Intézete és } \\
\text { II. Gyermekgyógyászati } \\
\text { Klinika }\end{array}$ & & $\begin{array}{l}\text { PTE Klinikai } \\
\text { Központ Orvosi } \\
\text { Genetikai Intézet }\end{array}$ & \\
\hline ERN LUNG & Tüdőbetegségek & & & & \\
\hline ERKNet & Vesebetegségek & & & & \\
\hline ERN Skin & Börrendellenességek & $\begin{array}{l}\text { SE Bőr-, Nemikórtani és } \\
\text { Bőronkológiai Klinika }\end{array}$ & $\begin{array}{l}\text { DE KK Bőr- } \\
\text { gyógyászati Klinika }\end{array}$ & & SzTE SZAKK \\
\hline ERN eUROGEN & Urogenitális betegségek & & & & \\
\hline ERN EpiCARE & Epilepsziák & & & & \\
\hline ERNICA & $\begin{array}{l}\text { Öröklött és veleszületett } \\
\text { rendellenességek }\end{array}$ & & & & \\
\hline ERN GENTURIS & $\begin{array}{l}\text { Genetikai tumorkockázatú } \\
\text { szindrómák }\end{array}$ & & & $\begin{array}{l}\text { PTE Klinikai } \\
\text { Központ Orvosi } \\
\text { Genetikai Intézet }\end{array}$ & \\
\hline ERN PaedCan & Gyermekrákok & $\begin{array}{l}\text { SE II. Gyermek- } \\
\text { gyógyászati Klinika }\end{array}$ & & & \\
\hline
\end{tabular}

DE KK RBSZK: Debreceni Egyetem Klinikai Központ Ritka Betegségek Szakértői Központ

PTE: Pécsi Tudományegyetem

SE: Semmelweis Egyetem, Budapest

SzTE: Szegedi Tudományegyetem

SZAKK: SzTE Szent-Györgyi Albert Klinikai Központ, Szeged 
külözhetetlen a ritka betegségek egészségügyi és kutatási információs rendszerekben történő megjelenésének javításához. A BNO-11-ben történő alkalmazásukig is az európai országok zöme elhatározta az Orpha-kódok használatát a BNO-10 alkalmazása mellett, annak kiegészítésére. E folyamat koordinálását hazánkban is államtitkári megbízott végzi. Az Orphanet egyben egy páratlan információs forrás is a ritka betegségek területén, amelynek célja, hogy magas színvonalú információt szolgáltasson a ritka betegségekről, és egyenlő hozzáférést biztosítson a kialakításra került tudásbázishoz minden érdekelt fél számára.

Ahhoz, hogy mind a szakmai, mind pedig a betegképviselet terén Magyarország jobban bekapcsolódhasson az európai rendszerekbe, nagyon fontos, hogy a szakértői központjaink, szakembereink és civil szervezeteink láthatóvá váljanak az Orphanet rendszerben (tehát regisztráljanak oda), és használják ellátómunkájuk során az Orpha-kódokat! Ezen a nagy gondon segít, hogy az Orpha-kódok bekerültek a hazai központi egészségügyi informatikai szolgáltatás (Elektronikus Egészségügyi Szolgáltatási Tér - EESzT) fogalomrendszerébe, a betegprofil adatai közé. Így harmonizálva az európai erőfeszítéssel [17] lehetővé válik, hogy a ritka betegségek láthatóvá váljanak.

\section{A RIROSZ és a Mentőöv Információs Központ és Segélyvonal szerepe}

Mivel a ritka betegek hátrányait és ellátásuk gondjait elsősorban az információk hiánya okozza, ezért hozta létre és múködteti a RIROSZ a Mentööv Információs Központot és Segélyvonalat, ezen a téren egyedüli hazai egészségügyi információs szolgáltatásként [18]. Célja, hogy a ritka betegséggel élők és környezetük időben juthasson a számukra szükséges, helytálló, szakszerú információhoz, és ennek birtokában megfelelő egészségügyi, szociális, oktatási ellátáshoz. Felhasználóbarát módon, sok csatornán és innovatívan, a tájékozódás mellett a kapott információ felhasználását is segíti. A hagyományos telefonhívásokat (segélyvonal: 061/790-4533) webes felületek mint e-mail, sorstárskereső közösségi portál, saját honlap (http://mentoov.rirosz.hu), hírlevél - és számos egyéb szolgáltatás egészíti ki. Az ellenőrzött és megbízható forrásból származó információk birtokában könnyebbé és gyorsabbá válhatnak a gyakran kanyargós betegutak. Ezzel nemcsak az egyes betegek élete válik könnyebbé, hanem az egészségügyi ellátórendszert is megkíméli a drága és szükségtelen vizsgálatok, beavatkozások elvégzésétől. A Mentőöo Információs Központ és Segélyvonal csatlakozott az Európai Ritka Betegségek Segélyvonalhálózathoz. A központ nemcsak a betegeknek tud információt és segítséget nyújtani, hanem az érintett szakembereknek és döntéshozóknak is. Ez utóbbiak számára az ellátásszervezést megnehezítő „láthatatlanság” okozta információhiányon segít a központ adatgyưjtése. A tájékoztatást adattárak és adattárakat múködtető szerveze- tekkel való együttmúködések alapozták meg (mint például az Orphanet).

A központ nem csak a ritka betegségekkel foglalkozó, szúk szakmai központok számára tud segítséget nyújtani. Kiemelten fontos lenne elérni, hogy egy adott beteg kivizsgálása során, már az alapellátásban, a napi gyakorlat szintjén is számoljanak a ritka betegség lehetőségével. Az alap-, illetve a szakellátó intézmények a további ellátás lehetőségeiről kaphatnak segítséget a Mentōövön keresztül.

A központ jövőbeli terveiben szerepel minél több ritkabeteg-család elérése, az egészségügyi dolgozók ritka betegségekkel kapcsolatos szakmai kompetenciájának fejlesztése, a szakmapolitika rendszeres informálása. Ezek összessége gyorsabb diagnózisokat, hatékonyabb, esetenként időben elkezdett kezeléseket eredményezne a betegeknél.

\section{Következtetés}

A ritka betegségek többsége életet veszélyeztető, krónikus lefolyású, korai halálozással vagy nagymértékú életminőség-romlással jár, míg más kórképek - korai felismerés és kezelés esetén - lehetővé teszik a normális életvitelt. Hosszú távon gyakran a fizikai és/vagy mentális képességek csökkenéséhez vezetnek, a gyermekek folyamatos ápolásra szorulhatnak, a felnőttkort megérők számos esetben képtelenek munkát vállalni, illetve állandó felügyeletet, gondozást igényelhetnek. A családok sokszor felbomlanak, nehéz gazdasági helyzetbe sodródnak, elszigetelődnek, a társadalom perifériájára szorulnak. Ugyanakkor nekik is joguk van a többiekével azonos esélyư gyógyuláshoz az igazságosság, egyenlőség és szolidaritás elve alapján. A ritka betegek nemcsak a társadalom többségével, hanem a többi beteggel szemben is hátrányos helyzetben vannak, nemcsak a betegség, hanem az általános információhiány és ennek következményei miatt.

E bonyolult és összetett probléma megoldására hazánkban is elkészült az átfogó, több diszciplínát egybefoglaló Ritka Betegségek Nemzeti Terve. E program célja volt a szakértői központok és betegutak kijelölése, hogy az érintetteknek javuljon a diagnózishoz és a megfelelő minőségú ellátáshoz való hozzáférése.

E nemzeti terv, a realitásokat figyelembe véve, nagyrészt a források átszervezését, koncentrációját, hatékonyabb felhasználását és szervezett múködését jelenti. A hatékony betegutak szervezésével és központokban történő ellátással rövidíthető a betegség felismerése és diagnosztizálása közt eltelt idő, elkerülhető a félrediagnosztizálás, s így összességében és hosszú távon csökkenthetők az egészségbiztosítás és szociális ellátás költségei.

A fentiek megvalósításának legfontosabb feltételei teremtődtek meg a Ritka Betegségek Szakértői Központjainak és az európai referenciahálózatoknak a létrehozásával. 
Mindehhez a RIROSZ és tagszervezetei a nemzeti tervvel összhangban létrehozott információs szolgáltatással igyekszik hozzájárulni. A Mentőöv Információs Központ és Segélyvonal segítségével az érdeklődő betegek és családtagjaik, a szakemberek és a döntéshozók is naprakész és hiteles információhoz juthatnak a ritka betegségekről, ellátásuk lehetséges módjairól, illetve arról, hogy kérdés esetén hova tudnak fordulni. Összeurópai felmérés szerint ez a ritka betegek által leginkább igényelt szociális szolgáltatás, amely relatív kis befektetéssel (körülbelül évi 10-40 millió Ft) fenntartható. Ezenfelül a nemzeti terv kivitelezésének fontos részeként a széles körű együttmúkködés kiváló példáját nyújtja, ezért célszerü kihasználni a benne rejlő lehetőségeket!

Anyagi támogatás: A közlemény megírása, illetve a kapcsolódó kutatómunka anyagi támogatásban nem részesült.

A cikk végleges változatát a szerző elolvasta és jóváhagyta.

Érdekeltségek: A szerzőnek családtagja érintettsége révén személyes érdekeltsége, hogy a ritka betegségek ügye Magyarországon is elörehaladjon.

\section{Köszönetnyilvánítás}

Köszönet illeti a RIROSZ és tagszervezetei képviselőit és vezetőit, valamint a Ritka Betegségek Szakértői Bizottságának tagjait.

\section{Irodalom}

[1] Regulation (EC) No 141/2000 of the European Parliament and of the Council of 16 December 1999 on orphan medicinal products. Official Journal of the European Communities 2000; L18 $1-5$.

[2] Schieppati A, Henter JI, Daina E, et al. Why rare diseases are an important medical and social issue. Lancet, 2008; 371: 20392041

[3] Rodwell C, Aymé S (eds.). "2014 Report on the State of the Art of Rare Disease Activities in Europe" Part I. Overview of Rare Disease Activities in Europe. July 2014. European Union, 2014.

[4] EURORDIS (European Organisation for Rare Diseases): „Rare diseases: understanding this public health priority." 2005.

[5] EURORDIS: The voice of 12000 patients. Experiences and expectations of rare disease patients on diagnosis and care in Europe. Paris, 2009
[6] Földvári A, Szy I, Sándor J, et al. Diagnostic delay of rare diseases in Europe and in Hungary. [A ritka betegségek diagnosztikájának késedelme Európában és Magyarországon.] Orv Hetil. 2012; 153: 1185-1190. [Hungarian]

[7] Pogány G. The present situation of rare diseases in central/eastern Europe? The role of patient organisations. Orphanet J Rare Dis. 2010; 5(Suppl 1): O30.

[8] Council Recommendation of 8 June 2009 on an action in the field of rare diseases. Official Journal of the European Union 2009, C151: 7-10.

[9] Kosztolányi Gy. Hungarian National Plan and Strategy for Rare Diseases. [Ritka Betegségek Nemzeti Terve.] Orv Hetil. 2014; 155: 325-328. [Hungarian]

[10] Pogány G. Rare diseases and their patient organization: the Hungarian Federation of People with Rare and Congenital Diseases. [A ritka betegségek és hazai betegszervezetük: a Ritka és Veleszületett Rendellenességgel Élók Országos Szövetsége.] Orv Hetil. 2014; 155: 329-333. [Hungarian]

[11] Collection of documents, related to development of Hungarian Rare Disease Plan. [A Ritka Betegségek Nemzeti Terve kidolgozásával kapcsolatos dokumentumok gyújteménye.] Available from: http://europlan.rirosz.hu [Hungarian]

[12] The webpage of Hungarian Rare Diseases Days. [A magyarországi Ritka Betegségek Világnapjai rendezvényeinek honlapja.] Available from: http://ritkanap.rirosz.hu [Hungarian]

[13] Organizational and Operational Rules of the Ministry of Human Capacities. [Az Emberi Erőforrások Minisztériumának Szervezeti és Múködési Szabályzata.] Available from: http://www. kormany.hu/download/7/64/01000/SZMSZ\%20egys\% C3\%A9ges\%20szerkezetben.pdf [Hungarian]

[14] Description of the EC policy of European Reference Networks (ERNs). [Az Európai Bizottság európai referenciahálózatokkal (ERH-k) kapcsolatos politikájának leírása.] Available from: http://ec.europa.eu/health/ern/policy_en

[15] Pfliegler Gy, Kovács E, Kovács G, et al. Adult-onset rare diseases. [Felnőttkorban kiteljesedő ritka kórképek.] Orv Hetil. 2014; 155: 334-340. [Hungarian]

[16] Péntek M, Herczegfalvi Á, Molnár MJ, et al. Disease burden of Duchenne muscular dystrophy patients and their caregivers. [Duchenne-féle izomdisztrófiával éló betegek és gondozóik betegségterhei.] Ideggyógy Szemle 2016; 69: 183-193. [Hungarian]

[17] Presentation of the RD-action activities concerning Orpha codes. [Az Orpha-kódokra vonatkozó RD-action tevékenység bemutatása.] Available from: http://www.rd-action.eu/workpackage/ workpackage- 5

[18] The webpage of the Lifebelt Information Centre and Helpline. [A Mentőöv Információs Központ és Segélyvonal honlapja.] Available from: http://mentoov.rirosz.hu/ [Hungarian]

(Pogány Gábor dr., Budapest, Orczy út 2., 1089 e-mail: pogany@rirosz.hu)

\title{
Felhívás előfizetésre
}

\author{
Legyen Olvasónk a következő évben is! \\ Fizessen elő az Orvosi Hetilap 2018-as évfolyamára! \\ Egy füzet ára: $950 \mathrm{Ft}$. \\ Éves előfizetési dij: $39900 \mathrm{Ft}$, nyugdíjasoknak: $29925 \mathrm{Ft}$. \\ Az online változat éves előfizetési dija: $24990 \mathrm{Ft}$.
}

